\title{
A multi-substrate approach for functional metagenomics-based screening for (hemi)cellulases in two wheat straw- degrading microbial consortia unveils novel thermoalkaliphilic enzymes
}

\author{
Mukil Maruthamuthu ${ }^{* \dagger}$, Diego Javier Jiménez ${ }^{\dagger}$, Patricia Stevens and Jan Dirk van Elsas
}

\begin{abstract}
Background: Functional metagenomics is a promising strategy for the exploration of the biocatalytic potential of microbiomes in order to uncover novel enzymes for industrial processes (e.g. biorefining or bleaching pulp). Most current methodologies used to screen for enzymes involved in plant biomass degradation are based on the use of single substrates. Moreover, highly diverse environments are used as metagenomic sources. However, such methods suffer from low hit rates of positive clones and hence the discovery of novel enzymatic activities from metagenomes has been hampered.

Results: Here, we constructed fosmid libraries from two wheat straw-degrading microbial consortia, denoted RWS (bred on untreated wheat straw) and TWS (bred on heat-treated wheat straw). Approximately 22,000 clones from each library were screened for (hemi)cellulose-degrading enzymes using a multi-chromogenic substrate approach. The screens yielded 71 positive clones for both libraries, giving hit rates of 1:440 and 1:1,047 for RWS and TWS, respectively. Seven clones (NT2-2, T5-5, NT18-17, T4-1, 10BT, NT18-21 and T17-2) were selected for sequence analyses. Their inserts revealed the presence of 18 genes encoding enzymes belonging to twelve different glycosyl hydrolase families $(\mathrm{GH} 2$, GH3, GH13, GH17, GH20, GH27, GH32, GH39, GH53, GH58, GH65 and GH109). These encompassed several carbohydrate-active gene clusters traceable mainly to Klebsiella related species. Detailed functional analyses showed that clone NT2-2 (containing a beta-galactosidase of $\sim 116 \mathrm{kDa}$ ) had highest enzymatic activity at $55^{\circ} \mathrm{C}$ and $\mathrm{pH} 9.0$. Additionally, clone T5-5 (containing a beta-xylosidase of $\sim 86 \mathrm{kDa}$ ) showed $>90 \%$ of enzymatic activity at $55^{\circ} \mathrm{C}$ and $\mathrm{pH} 10.0$.

Conclusions: This study employed a high-throughput method for rapid screening of fosmid metagenomic libraries for (hemi)cellulose-degrading enzymes. The approach, consisting of screens on multi-substrates coupled to further analyses, revealed high hit rates, as compared with recent other studies. Two clones, 10BT and T4-1, required the presence of multiple substrates for detectable activity, indicating a new avenue in library activity screening. Finally, clones NT2-2, T5-5 and NT18-17 were found to encode putative novel thermo-alkaline enzymes, which could represent a starting point for further biotechnological applications.
\end{abstract}

Keywords: Metagenomic libraries, Functional screening, Galactosidase, (Hemi)cellulose, Chromogenic substrates, Xylosidase

\footnotetext{
* Correspondence: m.marutha.muthu@rug.nl

${ }^{\dagger}$ Equal contributors

Department of Microbial Ecology, Groningen Institute for Evolutionary Life

Sciences, University of Groningen, Nijenborgh 7, 9747AG Groningen, The

Netherlands
} 


\section{Background}

Lignocellulose constitutes an abundant organic material that is recalcitrant to degradation. Across different plant species, it contains cellulose ( $35-50 \%)$ and hemicellulose ( 25-35\%) moieties that are complexed with lignin [1]. The cellulose moiety is a glucose polymer, whereas the hemicellulose part is composed of various pentose and hexose sugars (e.g. xylose, arabinose, mannose and galactose) linked by beta/alpha-glycosidic bonds [2-4]. All of these sugars have great value for the production of bioethanol, biodiesel and/or plastics $[5,6]$, and so there have been many efforts to release them from the plant matrix. However, current physicochemical methodologies for the degradation of plant biomass and subsequent production of sugars are imperfect [7] and so there is a great interest in the development of alternative and efficient processes, based on enzymes and/or lignocellulolytic microbes $[8,9]$.

The conversion of plant biomass to sugars requires the concerted action of different proteins, such as carbohydrate-binding modules ( $\mathrm{CBMs})$, polysaccharide monooxygenases, pectin lyases, hemicellulases, endoglucanases and beta-glucosidases [10-12]. Among the hemicellulases, xylosidases that can work efficiently at high temperatures in alkaline conditions are highly valued with respect to their usefulness in the pulp bleaching process [13, 14]. Actually, hemicellulases, which have previously been regarded as "accessory enzymes" of cellulases, may themselves exert vital roles in plant biomass hydrolysis $[15,16]$. Given the complexity of the enzymes required for efficient lignocellulose breakdown, multi-species microbial consortia offer interesting perspectives [17-20]. To unlock the biocatalytic potential present in lignocellulolytic microbial consortia, metagenomics-based approaches have been proposed [21-23]. Two different strategies can be used: i) the unleashing of high-throughput DNA sequencing on degradative consortia, and/or ii) the selection of enzymes via functional/genetic screening of metagenomic libraries produced from these consortia [9].

Functional metagenomic screening includes the detection of "positive clones" on the basis of phenotype (e.g. enzymatic activity), heterologous complementation and modulated detection by reporter genes [24]. As such, the approach does not depend on the availability of prior sequence information to detect enzymes and it therefore offers great potential to discover genetic novelty. Using this approach, searches for (hemi)cellulases have already been made in microbiomes from decaying wood, compost, rumen and soil [25-28]. However, only few studies have explored the enzymatic potential of microbial enrichments $[29,30]$. It is important to notice that functional screenings come with a possible caveat, which relates to the fact that the expression conditions in the heterologous host used need to match the requirements of the insert. Due to this and other caveats (e.g. improper codon usage and/or promoter recognition, inclusion body formation, toxicity of the gene product or inability of the host to induce the gene expression), the frequency with which positive clones are uncovered may be very low [31]. In attempts to overcome such low hit rates, some studies have applied "biased" (e.g. substrate-enriched environment) samples, coupled to the use of highly sensitive chromogenic substrates (e.g. 5-bromo-3-indolyl-beta-D-xylopyranoside) [32]. Other studies have used plasmid vectors with dualorientation promoters to obtain more positive clones [33]. The commonly-used substrates for screening for (hemi)cellulose-degrading enzymes include azo-dyed and azurine cross-linked polysaccharides (e.g. AZCL-HE-cellulose, AZCL-xylan or AZCL-beta-glucan), para-nitrophenyl glycosides (e.g. pNP-beta-D-cellobioside, pNP-alphagalactopyranoside or pNP-alpha-L-arabinofuranoside), carboxymethylcellulose and rimazol brilliant blue dyedxylan. However, multiple chromogenic substrates as proxies for functional screening for (hemi)cellulases have been underexplored, although, recently, these types of approaches were catalogued as highly interesting [34].

In this study, phylogenetically stable wheat strawdegrading microbial consortia [19-35] served as the sources for two fosmid-based metagenomic libraries. These libraries were subjected to expanded functional screens by a multi-substrate approach using six chromogenic compounds (indolyl-monosaccharides). Sequencing of the inserts of seven selected positive clones indicated the presence of a suite of novel genes encoding proteins of distinct glycosyl hydrolase $(\mathrm{GH})$ families, which were flanked mostly by CBMs and $\mathrm{ABC}$ transporters. Thus, we present an effective strategy for exploration of fosmid libraries for (hemi)cellulases, revealing hit rates higher than those reported in previous studies. Subsequent functional analyses unveiled genes encoding putative novel thermo-alkalinetolerant enzymes, which opens the way for future biotechnological applications (e.g. biorefining or bleaching pulp).

\section{Results \\ Construction and functional screening of two fosmid metagenomic libraries}

Two metagenomic libraries were produced in fosmids, one from pooled raw wheat straw (RWS) consortial DNA ( 70,000 clones) and another one from torrified wheat straw (TWS; 70,000 clones). Each library contained clones with inserts of $\sim 35 \mathrm{~kb}$ average size, yielding approximately $2.4 \mathrm{~Gb}$ of total cloned genomic DNA per library. In order to screen for (hemi)cellulose-degrading enzymes, about 22,000 clones per library were subjected to activity screens on LB agar supplemented with mixtures of six chromogenic substrates (Table 1; Fig. 1). These screens yielded a total of 71 positive hits, 
Table 1 Chromogenic substrates used in this study

\begin{tabular}{|c|c|c|c|c|c|}
\hline Activity on ${ }^{a}$ & Type of enzymes detected & Substrate (indolyl-monosaccharide) & Abbreviation & $\begin{array}{l}\text { Concentration } \\
\text { into the plate }\end{array}$ & Supplier \\
\hline \multirow[t]{4}{*}{ Hemicellulose } & alpha-fucosidases & 5-bromo-4-chloro-3-indolyl- -L-fucopyranoside & X-Fuc & \multirow[t]{6}{*}{ Each $40 \mathrm{~g} / \mathrm{ml}$} & \multirow{6}{*}{$\begin{array}{l}\text { Biosynth AG, } \\
\text { Switzerland }\end{array}$} \\
\hline & beta-galactosidases & 5-bromo-4-chloro-indolyl- $\beta$-D-galactopyranoside & X-Gal & & \\
\hline & beta-xylosidases & 5-bromo-4-chloro-3-indolyl- $\beta$-D-xylopyranoside & $x-X y l$ & & \\
\hline & alpha-mannosidases & 5-bromo-4-chloro-3-indolyl -D-mannopyranoside & X-Man & & \\
\hline \multirow[t]{2}{*}{ Cellulose and Starch } & beta-glucanases & 5-bromo-4-chloro-3-indolyl- $\beta$-D-cellobioside & X-Cel & & \\
\hline & alpha-glucosidases & 5-bromo-4-chloro-3-indolyl- -D-glucopyranoside & X-Glu & & \\
\hline
\end{tabular}

${ }^{\text {aActivity }}$ was predicted based on the linked monosaccharide

being 50 from RWS and 21 from TWS. This corresponded to, respectively, 1 hit per 440 screened clones (RWS), and 1 hit per 1,047 screened clones (TWS).

The 71 positive fosmid clones were restreaked to purity and then retested for activity to confirm the initial screening results. They were then subjected to additional plate screens with the hemicellulose-mimicking substrates XFuc, X-Gal, X-Xyl and X-Man, including single-, doubleand mixed-substrate plates. The 71 positive clones showed activity in the latter assay (mixed-substrate plate), confirming the initial data. Clones that showed consistent activities on the mixtures of six substrates but no activity on the aforementioned hemicellulose-mimicking substrates were then tested for their abilities to degrade cellulose or starch using X-Cel and X-Glu (single and double) (Fig. 1). After removal of clones with questionable activity (e.g. faint-blue colonies with white background), the remaining 52 clones showed consistent activities on at least one of the substrates tested. Specifically, 20 clones showed activity on X-Gal (18 from RWS - hit rate 1:1,157; 2 from TWS - hit rate 1:11,000), 9 on X-Xyl (all from TWS - hit rate 1:2,444) and 15 on X-Glu (all

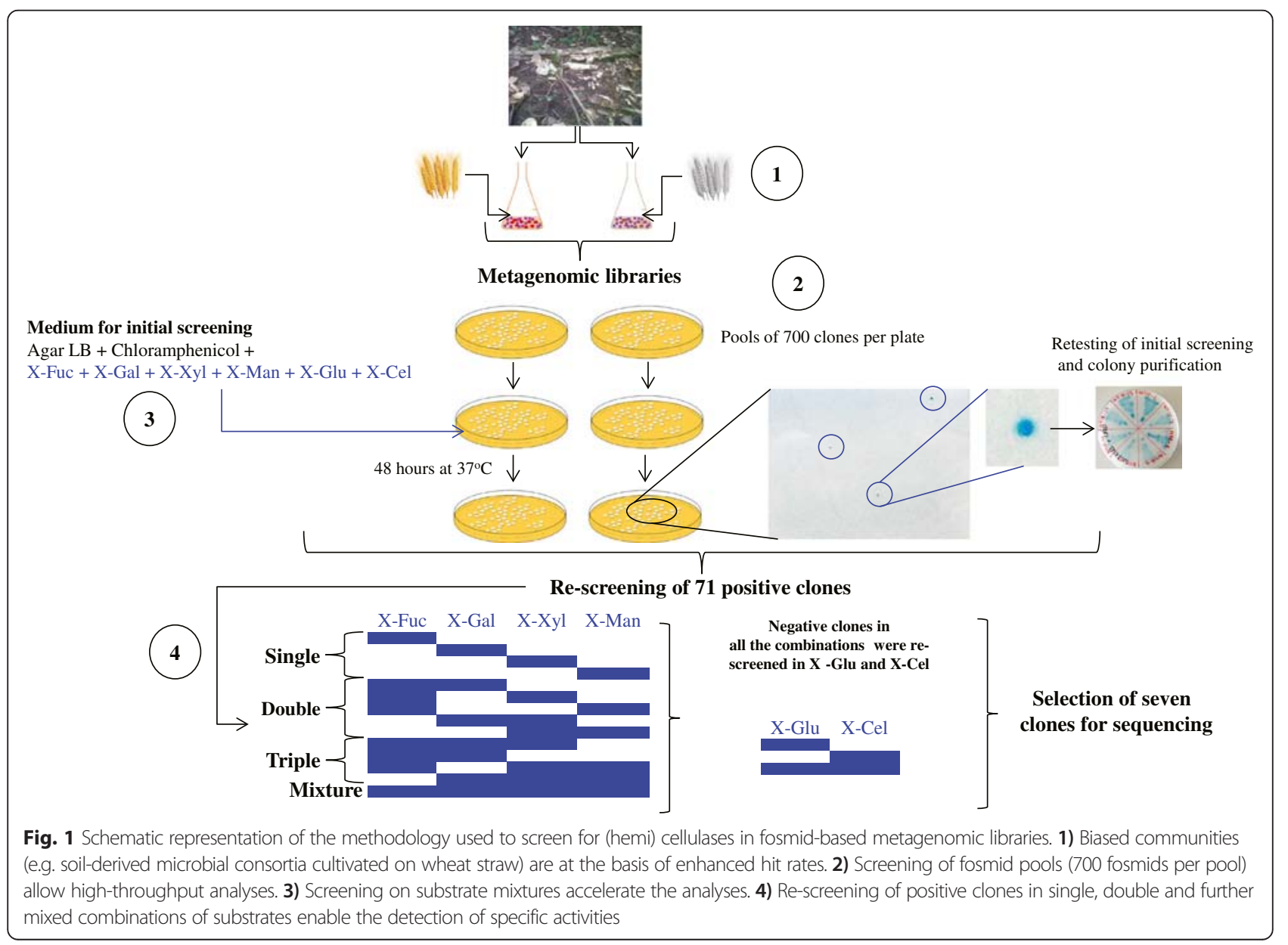


from RWS - hit rate 1:1,466) (as singletons). Remarkably, eight were positive only on the mixture of six substrates.

For each fosmid clone type in our library, as determined by activity, 2-4 clones were selected for genetic analysis. This selection was also guided by the clones' origin, i.e. RWS or TWS. Restriction with EcoR1 revealed, for all tested fosmids, the presence of insert sizes of approximately 28 to $35 \mathrm{~kb}$. It also allowed the detection of duplicates, for dereplication of the fosmid set. The, thus selected, final set of (seven) fosmids consisted of two clones that were positive for X-Gal (T17-2 and NT2-2), one for X-Xyl (T5-5), two for X-Glu (NT18-17 and NT18-21), and two with activity on multiple mixed substrates (10BT and T4-1) (Table 2).

\section{Analysis of fosmid insert sequences and detection of carbohydrate-active enzymes}

The seven selected clones (NT2-2, T5-5, NT18-17, T4-1, 10BT, NT18-21 and T17-2), were subjected to full insert sequencing. Final assembly of the inserts revealed a total of 15 contigs, of sizes between 3.0 and $35 \mathrm{~kb}$. Thus, some inserts had more than one contig, indicating the existence of regions with too low coverage. Per clone, the contigs were considered to be of sufficient representation to allow further analyses (Fig. 2). All contigs were then screened for the presence of open reading frames (ORFs) on the basis of the presence of start and stop codons (automatic annotation from the RAST server, followed by manual validation). In addition, the identified genes were, gene-by-gene, subjected to BLAST-based analyses, comparing against the NCBI and carbohydrateactive enzyme (CAZy) databases. Overall, we detected 18 promising ORFs encoding proteins from 12 different $\mathrm{GH}$ families amongst a total of 211 ORFs. The $\mathrm{G}+\mathrm{C}$ contents of the inserts ranged from 54.6 to $63.5 \%$. The complete annotation of each of the seven fosmid inserts is presented in the supplementary files. A brief description of each insert is listed below (Tables 2 and 3 ).

\section{Fosmid NT2-2}

Two contigs represented the total $31.2 \mathrm{~kb}$ insert, encompassing 26 predicted ORFs. The sizes of the identified ORFs ranged from 123 to 3,309 bp. Gene annotation revealed the presence of two predicted genes encoding proteins of $\mathrm{GH}$ families $\mathrm{GH} 2$ and GH53. The GH2encoding gene was annotated as a beta-galactosidase $(\sim 116 \mathrm{kDa})$ and could be correlated with the activity on $\mathrm{X}$-gal. Flanking this gene, genes predicted to encode two CBMs (CBM48 and CBM26), two glycosyl transferases (GTs) (GT2 and GT90) and an operon containing three methionine $\mathrm{ABC}$ transporter genes were found (Additional file 1).

\section{Fosmid T5-5}

Thirty predicted ORFs, with sizes ranging from 138 to $2,379 \mathrm{bp}$, were present in the $31.6 \mathrm{~kb}$ insert (composed of five contigs). A gene predicted to encode a 789-amino acid protein $(\sim 86 \mathrm{kDa})$ was annotated as a gene for beta-xylosidase. This protein could be involved in the detected enzymatic activity on X-Xyl. Flanking this gene, three $\mathrm{ABC}$ transporters, a xyloside transporter (Xyn'T - annotated as GH17 by CAZy) and a CBM50 gene (annotated as a lipoprotein by RAST) were found. In addition, predicted genes for carbohydrate-active enzymes of families CBM20, GH13 and GH32 were detected (Additional file 2).

\section{Fosmid NT18-17}

Thirty-five ORFs were identified in the $33.7 \mathrm{~kb}$ insert (two contigs). The insert showed a high $\mathrm{G}+\mathrm{C}$ content, i.e. $63.5 \%$. Four $\mathrm{GH}$-encoding genes were detected, which fell in the GH27, GH20, GH58 and GH109 families. Of these, two predicted proteins might be linked to the activity on X-Glu (GH58-hypothetical protein or GH27aquaporin). In addition, ten predicted $\mathrm{ABC}$ transporter genes were detected (Additional file 3).

Table 2 Selected fosmids for insert sequencing and annotation of genes

\begin{tabular}{|c|c|c|c|c|c|c|c|c|c|c|c|c|}
\hline \multirow[b]{2}{*}{ Fosmid ID } & \multirow[b]{2}{*}{ Positive on } & \multirow[b]{2}{*}{ \# Contigs (total length) } & \multirow[b]{2}{*}{$\%$ GC } & \multicolumn{9}{|c|}{ Number of genes based on RAST platform and CAZy database annotation } \\
\hline & & & & $\mathrm{GHs}$ & CBMs & AAs & GTs & CEs & $A B C$ & $\mathrm{H} / \mathrm{U}$ & Others & Total \\
\hline NT2-2 & $X-G a l$ & $2(31.21 \mathrm{~Kb})$ & 60.1 & 2 & 2 & 1 & 2 & 0 & 3 & 2 & 14 & 26 \\
\hline T5-5 & $x-x y l$ & $5(31.63 \mathrm{~Kb})$ & 51.9 & 4 & 2 & 0 & 0 & 0 & 3 & 8 & 13 & 30 \\
\hline NT18-17 & X-Glu & 2 (33.7 Kb) & 63.5 & 4 & 0 & 1 & 1 & 1 & 10 & 4 & 14 & 35 \\
\hline T4-1 & Mixed $^{a}$ & $2(34.84$ Kb) & 57.2 & 2 & 3 & 1 & 0 & 0 & 3 & 5 & 17 & 31 \\
\hline $10 B T$ & Mixed $^{a}$ & $2(31.87$ Kb) & 54.6 & 2 & 0 & 2 & 1 & 0 & 1 & 12 & 25 & 43 \\
\hline NT18-21 & X-Glu & $1(29.89$ Kb) & 55.0 & 0 & 1 & 0 & 0 & 0 & 3 & 2 & 21 & 27 \\
\hline T17-2 & X-Gal & $1(23.57 \mathrm{~Kb})$ & 54.8 & 4 & 1 & 0 & 2 & 0 & 0 & 3 & 9 & 19 \\
\hline
\end{tabular}

positive fosmids on the mixture of six chromogenic substrates, as in Table 1

$G H s$, glycosyl hydrolases, $C B M s$, carbohydrate binding modules, $A A s$, auxiliary activities, $G T s$, Glycosyl transferases, $C E s$, carbohydrate esterases $A B C$, $A B C$ transporters, $H / U$, Hypothetical and unknown genes 


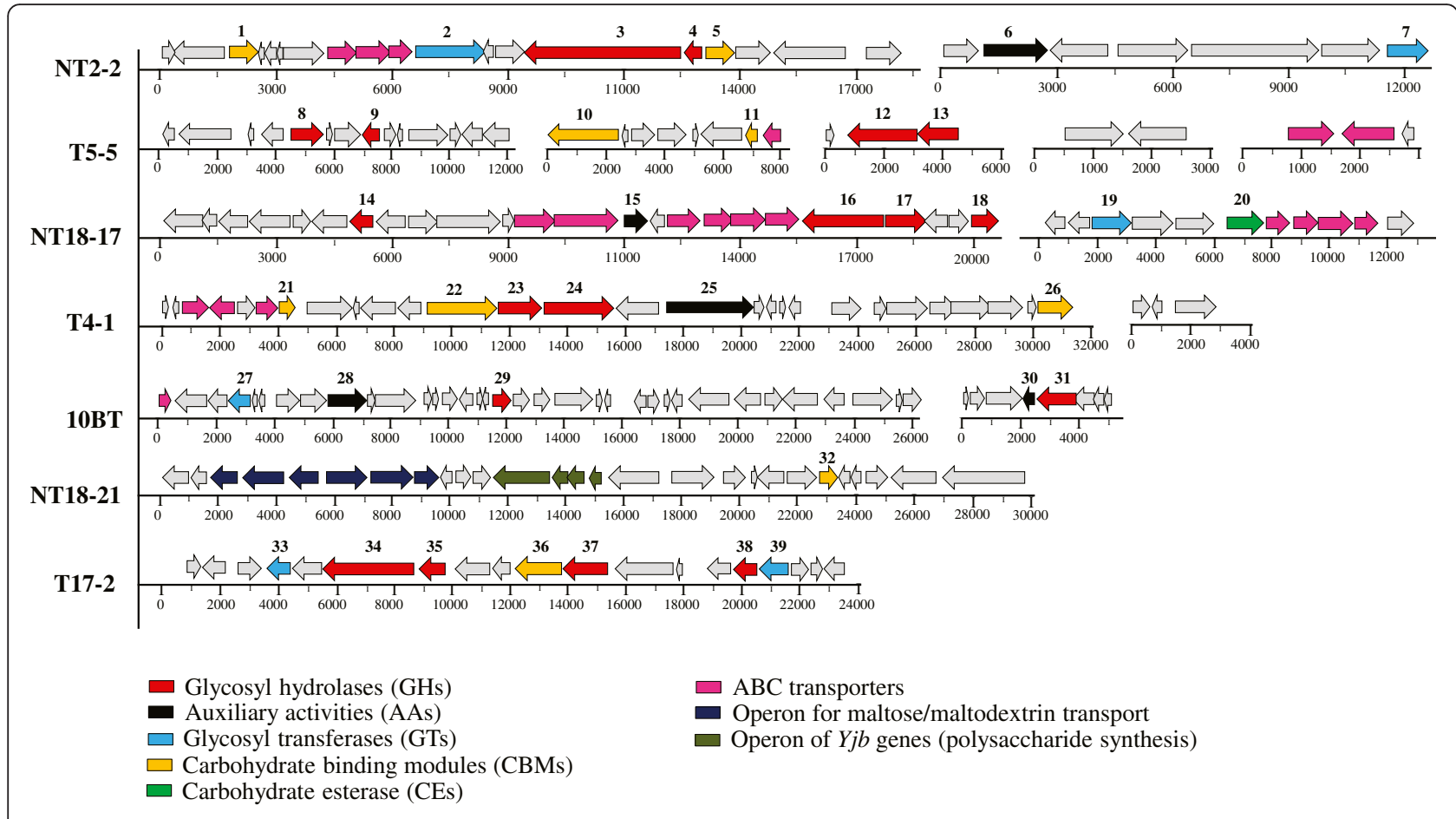

Fig. 2 Graphical representation of the genes detected and annotated in seven fosmid inserts selected by the multi-substrate screening approach

\section{Fosmid T4-1}

This contiguous insert $\left(\begin{array}{lll}31.4 & \mathrm{~kb}\end{array}\right)$ consisted of 31 ORFs, of sizes between 189 and 3,003 bp. Two genes with predicted $\mathrm{GH}$ activity were found. These might be involved in the enzymatic activities detected on mixed substrates, i.e. a GH3 family gene (encoding a beta-xylosidase) and a GH17 family one (annotated as a xyloside transporter; XynT). In addition, three genes predicted to encode CBMs were found in this insert (two CBM50 and one CBM20). The remainder encompassed either hypothetical and/or uncharacterized genes (five ORFs) or genes encoding different functions (seventeen ORFs) (Additional file 4).

\section{Fosmid 10BT}

Fourty-three ORFs were identified in the $31.8 \mathrm{~kb}$ insert of fosmid 10BT (two contigs). Consistent with the annotation, genes predicted to encode two GHs (i.e. GH39 and GH53), two auxiliary activities (AAs; AA5 and AA3), one GT (GT4) and one ABC transporter were identified. Of these, the newly discovered GH39 (beta-xylosidase) and GH53 (endo-beta-1,4-galactanase) genes could be related to the activities measured with the mixture of substrates. Interestingly, these genes were annotated -by RAST- as a transcriptional regulator (AraC family) and an inner membrane protein, $Y$ fiN, respectively (Additional file 5).

\section{Fosmid NT18-21}

Fosmid NT18-21 contained a 29.8 kb insert within a single contig. Although this insert contained a total of 27 predicted ORFs, CAZy annotation predicted only one gene with carbohydrate activity, i.e. one encoding CBM50 (identified by RAST as "shikimate 5dehydrogenase I gamma"). Furthermore, two operons were detected that might relate to the activity, one of them encompassing predicted genes for maltose/ maltodextrin transporters and the second one presumed polysaccharide synthesis genes (YjbH-YjbG$Y j b \mathrm{~F}-Y j b \mathrm{E})$. The latter operon was flanked by a gene for glucose-6-phosphate isomerase and one for an aspartokinase, which are both involved in sugar metabolism (Additional file 6).

\section{Fosmid T17-2}

Nineteen ORFs were identified within the $23.5 \mathrm{~kb}$ insert of fosmid T17-2 (one contig), which had a G + C content of $54.8 \%$. The ORFs had a size range between 117 and 3,084 bp. One ORF, encoding a 1,027-amino acid protein, was identified as a gene for beta-galactosidase (GH2 family), suggesting it was responsible for the activity of the fosmid on X-gal. In addition, we identified genes for the transcriptional repressor of the lac operon and "PTS system sucrose-specific IIB component", that were identified by CAZy as a GH53 and a GH32 family 
Table 3 Carbohydrate-active genes detected in each fosmid insert

\begin{tabular}{|c|c|c|c|c|c|}
\hline Fosmid ID & $\begin{array}{l}\text { ID gene } \\
\text { (Fig. 2) }\end{array}$ & $\begin{array}{l}\text { CAZy } \\
\text { Family }^{\text {a }}\end{array}$ & $\begin{array}{l}\text { Size in amino } \\
\text { acids }\left(\mathrm{kDa}^{\mathrm{b}}\right)\end{array}$ & $\begin{array}{l}\text { Annotation based on RAST } \\
\text { platform (EC number) }\end{array}$ & $\begin{array}{l}\text { Probable protein from } \\
\text { (identity / coverage) }\end{array}$ \\
\hline \multirow[t]{7}{*}{ NT2-2 } & 1 & CBM26 & 236 & GCN5-related N-acetyltransferase & Klebsiella oxytoca (73 \% / 83 \%) \\
\hline & 2 & GT2 & 521 & Uncharacterized protein YlaB & Enterobacter mori (58 \% / 74 \%) \\
\hline & $3^{c}$ & $\mathrm{GH} 2$ & $1028(116)$ & Beta-galactosidase (EC 3.2.1.23) & Enterobacter hormaechei (74 \% / 81 \%) \\
\hline & 4 & GH53 & 119 & Transcriptional repressor of the lac operon & Enterobacter hormaechei (59 \% / 75 \%) \\
\hline & 5 & CBM48 & 301 & Carboxyl-terminal protease (EC 3.4.21.102) & Pseudomonas putida (99 \% /100 \%) \\
\hline & 6 & AA3 & 565 & Choline dehydrogenase (EC 1.1.99.1) & Pseudomonas putida (99 \% / 99 \%) \\
\hline & 7 & GT90 & 144 & Thioredoxin & Pseudomonas putida (95 \% / 99 \%) \\
\hline \multirow[t]{6}{*}{ T5-5 } & 8 & $\mathrm{GH} 32$ & 310 & 6-Phosphofructokinase class II (EC 2.7.1.11) & Klebsiella oxytoca (92 \% / 97 \%) \\
\hline & 9 & GH13 & 241 & $\begin{array}{l}\text { Ferric siderophore transport system, } \\
\text { periplasmic binding protein TonB }\end{array}$ & Klebsiella pneumoniae (75 \% / 84 \%) \\
\hline & 10 & CBM20 & 792 & Phosphoenolpyruvate synthase (EC 2.7.9.2) & Klebsiella oxytoca (98 \% / 99 \%) \\
\hline & 11 & CBM50 & 154 & Probable lipoprotein NIpC precursor & Klebsiella oxytoca (98 \% /99 \%) \\
\hline & $12^{c}$ & $\mathrm{GH} 3$ & 789 (86) & Beta-xylosidase (EC 3.2.1.37) & Enterobacter mori (84 \% /91 \%) \\
\hline & 13 & $\mathrm{GH} 17$ & 465 & Xyloside transporter XynT & Enterobacter cloacae (82% / 90 \%) \\
\hline \multirow[t]{7}{*}{ NT18-17 } & $14^{\mathrm{c}}$ & $\mathrm{GH} 27$ & $218(22)$ & Aquaporin Z & Hyphomonas neptunium (65 \% / 80 \%) \\
\hline & 15 & AA6 & 195 & NAD(P)H oxidoreductase & Rhizobium etli (48 \% / 64 \%) \\
\hline & 16 & $\mathrm{GH} 20$ & 642 & Beta-hexosaminidase (EC 3.2.1.52) & $\begin{array}{l}\text { Rhizobium leguminosarum } 3841 \\
(50 \% \text { / } 64 \%)\end{array}$ \\
\hline & $17^{c}$ & GH58 & $356(38)$ & Hypothetical protein & $\begin{array}{l}\text { Hyphomicrobium denitrificans } \\
(56 \% / 71 \%)\end{array}$ \\
\hline & 18 & GH109 & 231 & Dehydrogenase & $\begin{array}{l}\text { Rhizobium leguminosarum } \\
\text { (58\% / } 76 \%)\end{array}$ \\
\hline & 19 & GT2 & 442 & $\begin{array}{l}\text { Omega-amino acid-pyruvate } \\
\text { aminotransferase (EC 2.6.1.18) }\end{array}$ & $\begin{array}{l}\text { Mesorhizobium opportunistum WSM207 } \\
(82 \% / 90 \%)\end{array}$ \\
\hline & 20 & CE9 & 483 & Dihydropyrimidinase (EC 3.5.2.2) & $\begin{array}{l}\text { Rhizobium leguminosarum } \\
(80 \% / 90 \%)\end{array}$ \\
\hline \multirow[t]{6}{*}{ T4-1 } & 21 & CBM50 & 154 & Probable lipoprotein NIpC precursor & Klebsiella oxytoca (92 \% / $99 \%)$ \\
\hline & 22 & CBM20 & 792 & Phosphoenolpyruvate synthase (EC 2.7.9.2) & Klebsiella oxytoca (98 \% / 99 \%) \\
\hline & $23^{c}$ & $\mathrm{GH} 17$ & $465(52)$ & Xyloside transporter XynT & Enterobacter cloacae (82 \% / 90 \%) \\
\hline & $24^{c}$ & $\mathrm{GH} 3$ & $789(86)$ & Beta-xylosidase (EC 3.2.1.37) & Enterobacter mori (83 \% / 90 \%) \\
\hline & 25 & AA4/AA7 & 1000 & $\begin{array}{l}\text { Glycolate dehydrogenase (EC 1.1.99.14), } \\
\text { subunit GlcD }\end{array}$ & Klebsiella oxytoca (95 \% / $98 \%)$ \\
\hline & 26 & CBM50 & 332 & L,D-transpeptidase YnhG & Klebsiella oxytoca (85 \% / 93 \%) \\
\hline \multirow[t]{5}{*}{ 10BT } & 27 & GT4 & 239 & $\begin{array}{l}\text { Thioesterase involved in non-ribosomal } \\
\text { peptide biosynthesis }\end{array}$ & Pseudomonas putida (90 \% / 93 \%) \\
\hline & 28 & AA3 & 413 & Sarcosine oxidase beta subunit (EC 1.5.3.1) & Pseudomonas putida (98 \% / 99 \%) \\
\hline & $29^{c}$ & GH39 & $192(21)$ & Transcriptional regulator, AraC family & Klebsiella oxytoca (76 \% / 87 \%) \\
\hline & 30 & AA5 & 127 & Integral membrane protein YfiB & $\begin{array}{l}\text { Enterobacter cancerogenus } \\
(90 \% / 94 \%)\end{array}$ \\
\hline & $31^{c}$ & GH53 & $406(46)$ & Inner membrane protein YfiN & Enterobacter cloacae (79 \% / 88 \%) \\
\hline NT18-21 & 32 & CBM50 & 396 & $\begin{array}{l}\text { Shikimate 5-dehydrogenase I gamma } \\
\text { (EC 1.1.1.25) }\end{array}$ & Klebsiella oxytoca (83 \% / 90 \%) \\
\hline \multirow[t]{5}{*}{$\mathrm{T} 17-2$} & 33 & GT8 & 207 & Galactoside O-acetyltransferase (EC 2.3.1.18) & Escherichia coli (81 \% / 93 \%) \\
\hline & $34^{c}$ & $\mathrm{GH} 2$ & $1027(116)$ & Beta-galactosidase (EC 3.2.1.23) & Citrobacter freundii (87 \% / $92 \%)$ \\
\hline & 35 & GH53 & 360 & Transcriptional repressor of the lac operon & Citrobacter koseri (89 \% / $94 \%)$ \\
\hline & 36 & CBM51 & 581 & Choline-sulfatase (EC 3.1.6.6) & Klebsiella oxytoca (94 \% / 97 \%) \\
\hline & 37 & $\mathrm{GH} 32$ & 471 & PTS system, sucrose-specific IIB component & Klebsiella oxytoca (94 \% / $97 \%)$ \\
\hline
\end{tabular}


Table 3 Carbohydrate-active genes detected in each fosmid insert (Continued)

\begin{tabular}{cllll}
\hline 38 & GH65/GT5 & 266 & $\begin{array}{l}\text { Cof, detected in genetic screen for } \\
\text { thiamin metabolic genes } \\
\text { Lysophospholipase L2 (EC 3.1.1.5) }\end{array}$ & Klebsiella oxytoca (94\% / 97 \%) \\
\hline
\end{tabular}

${ }^{a}$ Annotation using the CAZymes Analysis Toolkit (CAT) platform

${ }^{\mathrm{b}}$ Predictive molecular size in $\mathrm{kDa}$

c correspond to genes predicted to be involved in the detected enzymatic activities

proteins, respectively. Two genes encoding GTs (GT4 and GT8), and one gene for CBM51 were also identified (Additional file 7).

\section{Tracking the microbial sources of the fosmid inserts}

To identify the potential microbial source of each metagenomic insert, the predicted amino acid sequences per gene per contig were BLAST-compared to the NCBI database. In addition, such BLAST results were analyzed by the Lowest Common Ancestor (LCA) algorithm in MEGAN v5 (Additional files). Thus, 14 predicted protein sequences from the NT2-2 insert were affiliated to proteins of members of the Enterobacteriaceae, notably Klebsiella oxytoca and Enterobacter sp. However, another 11 predicted proteins from this insert were affiliated, based on the 50 "best" BLAST hits, to those from Pseudomonas putida. In the fosmid T5-5 insert, 27 predicted proteins were mainly related to Klebsiella oxytoca -derived proteins. The insert of fosmid NT1817 showed a complexity of genes that were affiliated to different genera (e.g. Pelagibacterium, Rhizobium and Mesorhizobium). These genera all belong to the Rhizobiales, suggesting an organism from this group as the most likely source. In both fosmids T4-1 and NT18-21, virtually all predicted proteins (approximately $96 \%$ ) were affiliated with proteins from members of the Enterobacteriaceae. Closer (manual) screening of the data indicated that insert T4-1 might come from a Klebsiella oxytoca -like organism, whereas insert NT18-21 might originate from an organism affiliated with either Citrobacter, Klebsiella or Salmonella. A similar observation was made for the fosmid T17-2 insert. In the case of fosmid 10BT, eleven ORFs yielded predicted proteins that resembled those of Pseudomonas putida -like organisms (coverage and identity of $>90 \%$ ), whereas the remainder of the predicted proteins were more related to those from enteric species (e.g. mostly Klebsiella oxytoca like). This was similar to what was shown for the NT2-2 insert.

\section{Functional analyses: beta-galactosidase, beta-xylanase and alpha-glucosidase activities}

Based on the initially-detected activities of the fosmid clones, we selected three commercially available substrates, i.e. para-nitrophenyl-beta-D-galactopyranoside (pNPGal), para-nitrophenyl-beta-D-xylanopyranoside (pNPXyl) and
para-nitrophenyl-alpha-D-glucopyranoside (pNPGlu), in order to quantify the activities (using total protein extracts) at different temperatures and $\mathrm{pH}$ values. Clones NT2-2 and T17-2 were positive on pNPGal, confirming the initial screening data, while clones T5-5, T4-1 and 10BT were positive on pNPXyl. In addition, clone NT18-17 showed activity on pNPGlu (Fig. 3a). Clones NT2-2 and T5-5 showed elevated levels of enzymatic activity and were therefore chosen for further assays (Fig. 3b,d). Total protein extracts produced from the fosmid-less host (E. coli EPI 300) did not show any activity on the selected pNP substrates, confirming that the activities came from the metagenomic inserts.

For clone NT2-2, activity on pNPGal was maximal at $55{ }^{\circ} \mathrm{C}$ and $\mathrm{pH} 9.0$ (between 3,516 $\pm 219.02 \mathrm{U} / \mathrm{mg}$ and $3,377 \pm 47.19 \mathrm{U} / \mathrm{mg}$ ), with $34 \%$ and $44 \%$ of activity remaining at $80{ }^{\circ} \mathrm{C}$ and $\mathrm{pH} 10.0$, respectively. Activity was not detected below pH 6.0 (Fig. 4a,b). The activity of clone T5-5 on pNPXyl was maximal at $55{ }^{\circ} \mathrm{C}$, with values of around 93, 21 and $12 \%$ of this maximum at 37, 70 and $22{ }^{\circ} \mathrm{C}$, respectively. The highest xylanolytic activity for clone T5-5 was obtained at $55^{\circ} \mathrm{C}$ and $\mathrm{pH} 8.0$ $(3.96 \pm 0.04 \mathrm{U} / \mathrm{mg})$, with $\sim 91 \%$ of activity remaining at $\mathrm{pH}$ 10.0. The enzyme produced by T5-5 was likely alkaliphilic. Similar to clone NT2-2, T5-5 activity was not detected at $\mathrm{pH}$ values below 6.0 (Fig. 4c,d). Finally, clone NT18-17 showed maximum activity at pH 7.0 and $55^{\circ} \mathrm{C}$ $(1.87 \pm 0.06 \mathrm{U} / \mathrm{mg})$, with about $0.94 \mathrm{U} / \mathrm{mg}$ at $40{ }^{\circ} \mathrm{C}$ and $\mathrm{pH}$ 10.0. This suggested this enzyme was quite tolerant to alkaline conditions (Fig. 4e,f).

\section{Zymograms}

Native polyacrylamide gels showed that crude protein extracts from the seven fosmid clones had band patterns different from those of the E. coli EPI300 host. Moreover, none of the bands produced from the E. coli EPI300 host were positive with MUFGal (MUF-beta-Dgalactopyranoside) and MUFXyl (MUF-beta-D-xylopyranoside) (used as substrates), confirming that any activities measured came from the metagenomic inserts. Clones NT2-2 and T17-2 both showed a band of $>100 \mathrm{kDa}$ with high activity on MUFGal (Fig. 5). Given their estimated sizes, these bands likely represent proteins encoded by genes 3 and 34 (Fig. 2; both beta-galactosidase encoding genes). Clone T4-1 showed a band of 75-100 kDa size, with xylosidase activity, which is consistent with the initial 
A)

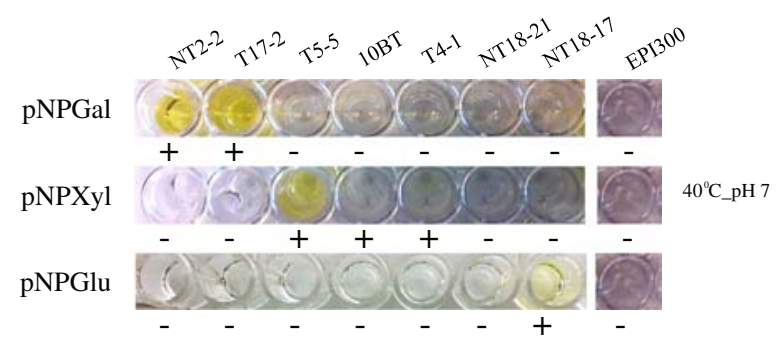

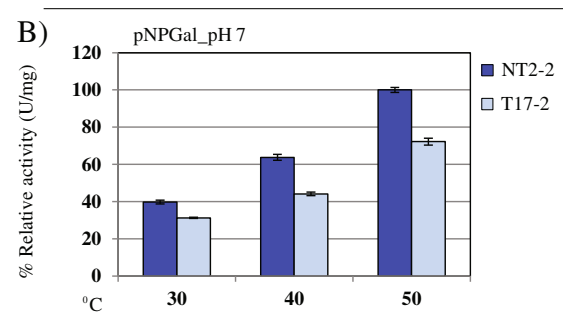

C)

है

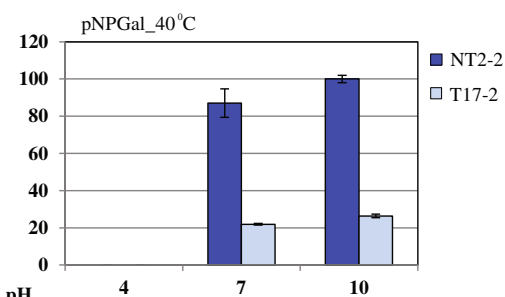

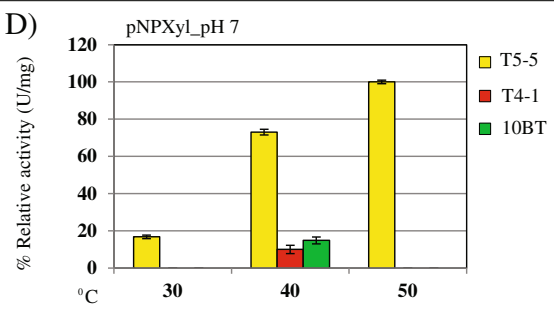

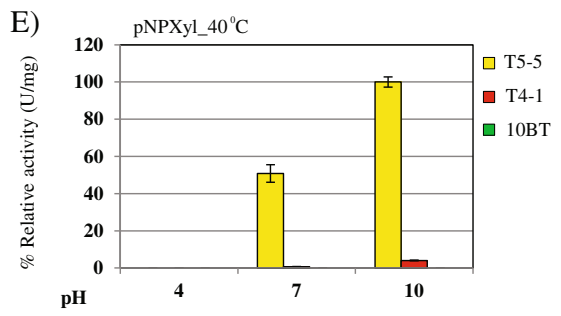

Fig. 3 Functional analyses (relative enzymatic activities, expressed in U/mg) based on total proteins extracted from selected positive fosmid clones. a Characterization of the fosmid clones using three pNP-substrates (pNPGal, pNPXyl and pNPGlu). $\mathbf{b}$ and $\mathbf{c}$ Effect of temperature and pH on the activity of clones NT2-2 and T17-2 with pNPGal. $\mathbf{d}$ and e Effect of temperature and pH on the activity of clones T5-5, T4-1 and 10BT with pNPXyl

finding of activity on pNPXyl. This band likely corresponds to a protein encoded by gene 24 (Table 3), predicted to be a beta-xylosidase of $\sim 86 \mathrm{kDa}$. Clones T5-5 and 10BT, positive with pNPXyl, did not show any bands with activity on the zymograms using MUFXyl.

\section{Discussion}

In this study, two wheat straw-degrading microbial consortia, RWS and TWS, were successfully subjected to metagenomic library constructions using fosmids, yielding $2.4 \mathrm{~Gb}$ of genomic information per library. Taking an estimated average bacterial genome size in our microbial consortia of $4 \mathrm{Mb}$ and considering these were strongly dominated by bacteria, we thus cloned the equivalent of roughly 600 bacterial genomes. Previous data on the two consortia [35] revealed the presence of $\sim 100$ (RWS) and $\sim 50$ (TWS) dominant bacterial types, in relative abundances within one log unit, giving a coverage of around six-fold for RWS and twelve-fold for TWS. Hence, a back-of-the-envelope calculation revealed that we basically covered the genes from most of the dominant bacterial members in the degrader consortia.
To detect (hemi)cellulolytic enzymes by functional screenings, two alternative strategies can be followed: 1) high-throughput detection in agar plates (mostly secreted enzymes) using hydrolysis of a chromogenic substrate as the criterion and 2) detection of enzyme activity in crude extracts after cell lysis. In either methodology, additional factors should be taken into account. These are the vector copy number, the need for induction of gene expression, secretion of the enzyme and recovery of the vector plasmid after expression [31, 36]. Here, we tested our fosmids by functional screenings for (hemi)cellulases initially using a mixture of (six) chromogenic compounds in agar plates. These substrates (indolyl-monosaccharides) can be internalized by $E$. coli and are thus readily available for hydrolysis by intracellularly-expressed exo-glycosidases. This is not the case for substrates such as oat spelt xylan or CMC, the hydrolysis of which relies on the release of fosmid-expressed enzymes, which probably only occurs after cell death and lysis [32]. The substrates were organic compounds, each consisting of a monosaccharide linked to a substituted indole moiety. The substrates yield insoluble blue compounds as a result of enzymecatalyzed hydrolysis. For example, X-Xyl, when cleaved by beta-xylosidase, yields xylose and 5-bromo-4-chloro- 


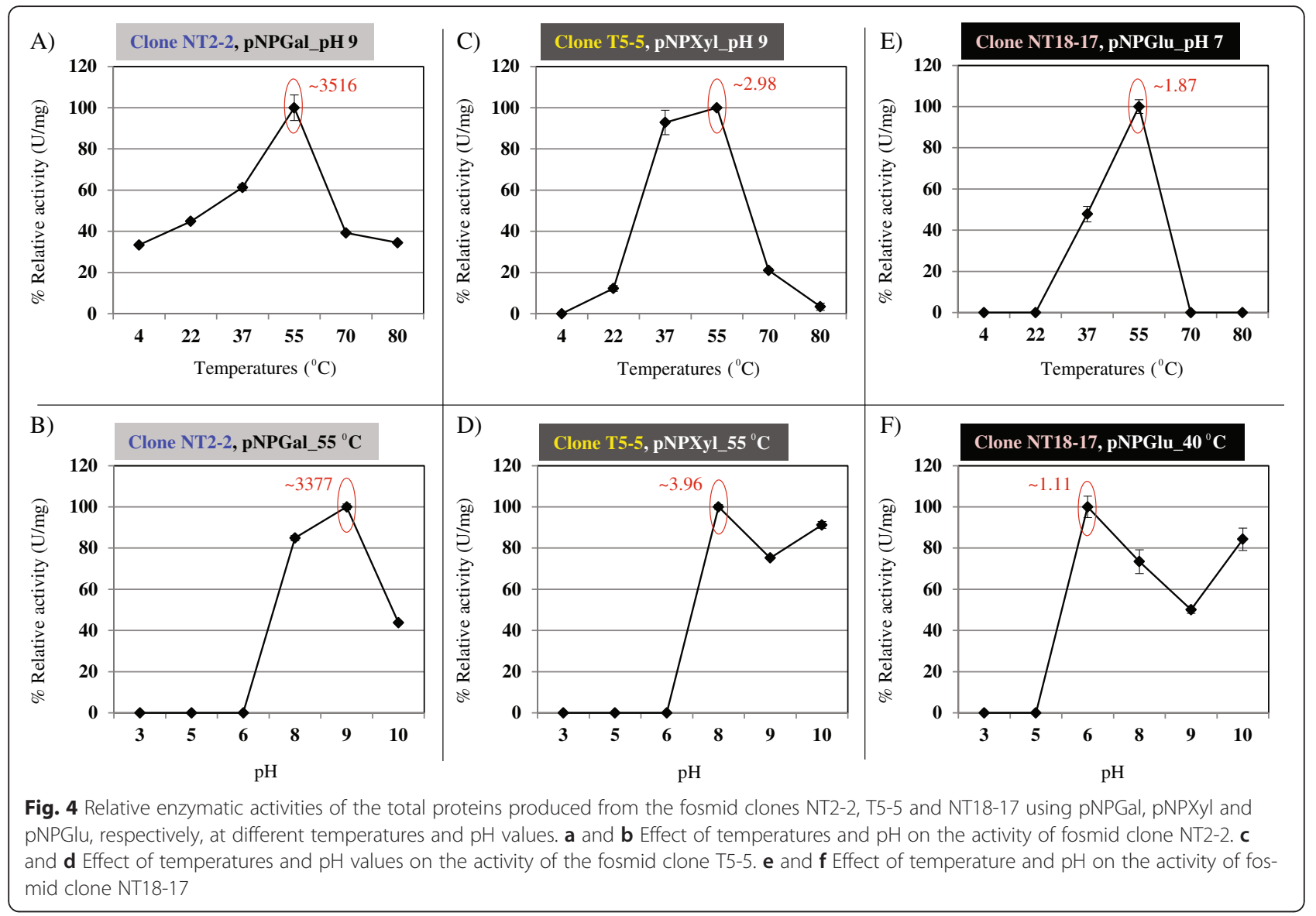

3-hydroxyindole. The latter compound can spontaneously dimerize and is oxidized into 5,5'-dibromo-4,4' dichloro-indigo, an intensely blue product which is insoluble. Taking into account the structure of these substrates, we hypothesized that the approach allows the screening for debranching enzymes that act in the external chains of sugars (in this case fucose, xylose, galactose, mannose and glucose) and that are linked to the backbone of the (hemi)cellulose structures. Indeed, our multi-substrate approach is also applicable in
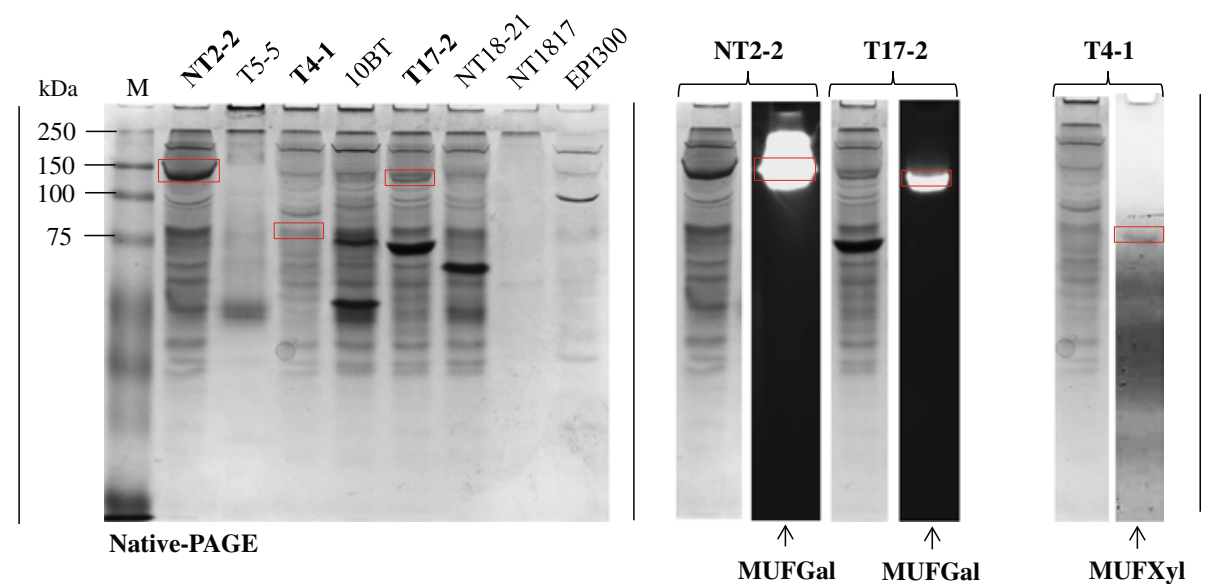

Fig. 5 Native polyacrylamide gel electrophoresis (Native-PAGE) and zymogram analysis. Left: Native polyacrylamide gel of the total proteins from the positive fosmid clones. Right: Positive fosmid clones that showed bands (red square) with activity on the zymogram assay using MUFGal (MUF-beta-D-galactopyranoside) and MUFXyl (MUF-beta-D-xylopyranoside) as substrates 
screens of metagenomic libraries for other classes of enzymes, as long as chromogenic substrates are available for that purpose. For example, to detect lipolytic activity, 5-(4-hydroxy-3,5-dimethoxyphenylmethylene)2-thioxothia-zolidin-4-one-3-ethanoic acid (SRA)-propionate, SRA-butyrate, SRA-octanoate, SRA-decanoate, SRA-laurate and SRA-myristate can be employed [37].

Given our high hit rates, i.e.1:440 in RWS and 1:1,047 in TWS, the multi-substrate screening approach was superior to approaches reported in the recent literature (Table 4). On the other hand, in both libraries the hit rates for the individual enzymes were $<1: 2,500$, except for X-Gal in RWS $(1: 11,000)$. Comparing 15 different metagenomic libraries and 19 single substrates, we inferred an average hit rate of (hemi)cellulolytic activities of $\sim 1: 7,300$. However, some approaches showed hit rates of $<1: 2,000$. Additionally, low hit rates were found (in recent studies) using chromogenic substrates (e.g. X-Xyl) or azurine cross-linked polysaccharides. Interestingly, Zhao et al. [38], screening a BAC vector library produced from a cow rumen microbiome, reported a hit rate of 1:853 using xylan as the screening substrate. Nguyen et al. [39], screening their buffalo rumen metagenomic library, found hit rates of 1:108 and 1:2,500 using AZCL-HE-cellulose and AZCL-xylan, respectively. The authors suggested that the relatively high hit rate on AZCL-HE-cellulose can be attributed to the use of ENZhance cell permeabilizing reagent. These results emphasize the advantages of combining large-insert libraries (maximizing the probability of identifying gene clusters whose components perform complementary functions), enriched-function systems (such as the cow rumen) and reagents that enhance the host cell permeabilities, allowing the release of enzymes.

Here, "biased" communities were produced on wheat straw as the carbon source and energy, which is thought to raise the relative abundance of target genes in the consortium and thus in the fosmid clones. However, Mori et al. [29], using a pUC19 library produced from pulp enrichments, obtained a hit rate of only 1:63,000 with rimazol brilliant blue dyed-Xylan. Beloqui et al. [30] reported a hit rate of 1:2,090 in a library prepared from filter paper -enrichments inoculated from earthworm gut extract, using as the screening substrate pNP-betaD-glucopyranoside. Another interesting approach that potentially leads to highly efficient discovery of GH activities is the construction of metagenomic libraries prepared from DNA selected following stable isotope probing (DNA-SIP) using multiple labeled plant-derived carbon substrates. For example, Verastegui et al. [40] showed a hit rate of 1:360 using DNA from ${ }^{13} \mathrm{C}$-cellulose-enriched incubations on the basis of CMC as the substrate (Table 4). Clearly, the rates of obtaining positive clones are related to the cloning vector used, the metagenome source, the screening technique (substrates and desired activity) and the host cells. On top of that, in many cases stochastic (chance) factors play a role as well, which may relate to the relatively low sample sizes [36].

In functional screening of metagenomic libraries, proper selection of the substrate is highly recommended. Initial selection of substrate-active clones with "general" substrates or mixtures of substrates followed by more specific ones may represent a desirable "layered" approach. Recently, a new generation of multi-colored chromogenic polysaccharide substrates has been developed [41]. These substrates can be used to screen for GH activities (in this case, focusing on endo-enzymes). They show versatility and are convenient for high-throughput analyses for first-level screenings. Additionally, substrates representing -at least partially- the complexity of plant cell walls were produced, enabling activity screens on "real-world" plant polysaccharides.

In our study, four fosmid inserts carried genes that could be directly linked to the enzymatic activities based on homologies to known enzymes and predicted and detected protein sizes. Thus, proteins of predicted sizes (1,027 and 1,028 amino acids, giving proteins of $\sim 116 \mathrm{kDa}$ ) from fosmids NT2-2 and T17-2 (selected as positive on X-Gal) did transform pNPGal and MUFGal (zymogram). These were both annotated as betagalactosidases of family GH2 (EC 3.2.1.23) (Table 3). Fosmids T5-5 and T4-1, positive on X-Xyl/pNPXyl and mixed chromogenic substrates, respectively, revealed the presence of genes predicted to produce proteins of 789 amino acids $(\sim 86 \mathrm{kDa})$, which were annotated as beta-xylosidases of family GH3 (EC 3.2.1.37). Interesting, fosmid T4-1 showed activity only on the substrate mixes, but not on single $\mathrm{X}$-Xyl. This clone showed slight activity on pNPXyl $\left(0.113 \pm 0.002 \mathrm{U} / \mathrm{mg}\right.$ at $40{ }^{\circ} \mathrm{C}$, $\mathrm{pH}$ 7.0) and revealed a protein of size between 75 to $100 \mathrm{kDa}$, which was likely encoded by gene 24 (Table 3 ). The protein was positive on the zymogram using MUFXyl as a substrate (Fig. 5). The expression of this GH3 family gene may be regulated by the presence of the other substrates. Based on this rationale, on X-Xyl alone its activity might not be detected, whereas the presence of other substrates might spur activity, similar to what may happen in nature. Such a finding opens up a new paradigm in the screening of active enzymes from metagenomic libraries. Interestingly, in fosmid T4-1 a predicted xyloside transporter gene $(X y n \mathrm{~T})$ was detected, which matched the CAZy GH17 family. Proteins from this family can have glucan endo-1,3-beta-glucosidase activity, suggesting a possible involvement in activity on mixed substrates.

Although fosmid NT18-17 was positive on X-Glu and pNPGlu, we did not detect any gene related with its 
Table 4 Comparison of functional metagenomic approaches to screen for (hemi)cellulases

\begin{tabular}{|c|c|c|c|c|c|}
\hline $\begin{array}{l}\text { Microbial source } \\
\text { (enrichment bred from) }\end{array}$ & Vector / Host & $\begin{array}{l}\text { Screened } \\
\text { clones }\end{array}$ & Substrates for (hemi)cellulases screening & Hit rate $^{f}$ & Reference \\
\hline Cow rumen & pCCl-BAC a E. coli EPI300 & 15360 & Xylan & $1 / 853$ & $\begin{array}{l}\text { Zhao et al. } \\
\text { (2010) [38] }\end{array}$ \\
\hline \multirow[t]{3}{*}{ Termite gut } & \multirow[t]{3}{*}{$\mathrm{pCC} \mathrm{FOS}^{\mathrm{b}} /$ /E. coli EPI100 } & 40000 & 5-Bromo-3-indolyl-beta-D-xylopyranoside & $1 / 740$ & \multirow{3}{*}{$\begin{array}{l}\text { Bastien et al. } \\
\text { (2013) [32] }\end{array}$} \\
\hline & & 40000 & $\begin{array}{l}\text { 5-bromo-4-chloro-3-indolyl-alpha-L- } \\
\text { arabinofuranoside }\end{array}$ & $1 / 1.212$ & \\
\hline & & 40000 & Oat AZCl-xylan & $1 / 4.444$ & \\
\hline Cow rumen & pCCFOS b / E. coli EPI300-T1 & 17000 & $\begin{array}{l}\text { pNP-beta-D-glucopyranoside + pNP-beta- } \\
\text { D-cellobioside }\end{array}$ & $1 / 5.666$ & $\begin{array}{l}\text { Del Pozo et al. } \\
\text { (2012) [16] }\end{array}$ \\
\hline \multirow[t]{2}{*}{ Buffalo rumen } & \multirow[t]{2}{*}{ pCCFOS1 b / EPI300-T1 } & 10000 & AZCL-HE-cellulose & $1: 108$ & \multirow{2}{*}{$\begin{array}{l}\text { Nguyen et al. } \\
(2012)[39]\end{array}$} \\
\hline & & 10000 & AZCL-xylan & $1: 2.500$ & \\
\hline Avicel- enrichment culture (soil) & \multirow[t]{2}{*}{$\mathrm{pUC19}$ c / E. coli DH5 } & 57000 & Rimazol brilliant blue dyed-CMC & $1 / 7.125$ & \multirow{2}{*}{$\begin{array}{l}\text { Mori et al. } \\
\text { (2014) [29] }\end{array}$} \\
\hline Pulp- enrichment culture (soil) & & 63000 & Rimazol brilliant blue dyed-xylan & $1 / 63.000$ & \\
\hline Ikaite tufa columns & pGNS-BAC a / E.coli DH10B & 2843 & $\begin{array}{l}\text { 5-bromo-4-chloro-3-indolyl-beta-d- } \\
\text { galactopyranoside }\end{array}$ & $1 / 1.421$ & $\begin{array}{l}\text { Vester et al. } \\
\text { (2014) [49] }\end{array}$ \\
\hline \multirow[t]{2}{*}{ Grassland soil } & \multirow[t]{2}{*}{ pCC1FOS ${ }^{\text {b }}$ / E. coli EPI300 } & 4600 & Dye-labeled hydroxyethyl xylan & $1 / 4.600$ & \multirow{2}{*}{$\begin{array}{l}\text { Nacke et al. } \\
\text { (2012) [28] }\end{array}$} \\
\hline & & 4600 & Dye-labeled hydroxyethyl cellulose & $1 / 2.300$ & \\
\hline \multirow[t]{3}{*}{ Human gut } & \multirow[t]{3}{*}{$\mathrm{pCC1FOS}^{\text {b }} /$ E. coli EPI300 } & 156000 & AZCL-xylan & $1 / 4.588$ & \multirow{3}{*}{$\begin{array}{l}\text { Tasse et al. } \\
(2010)[50]\end{array}$} \\
\hline & & 156000 & AZCL-beta-glucan & $1 / 1.772$ & \\
\hline & & 136000 & AZCL-galactan & $1 / 1.271$ & \\
\hline $\begin{array}{l}\text { Filter paper -enrichment culture } \\
\text { (Earthworm) }\end{array}$ & 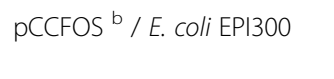 & 115000 & pNP-beta-D-glucopyranoside & $1 / 2.090$ & $\begin{array}{l}\text { Beloqui et al. } \\
\text { (2010) [30] }\end{array}$ \\
\hline Compost from pig manure & pCC2FOS ${ }^{b}$ / E. coli EPI300 & 12380 & Xylan & $1 / 2.476$ & $\begin{array}{l}\text { Jeong et al. } \\
\text { (2012) [51] }\end{array}$ \\
\hline Forest soil & $\begin{array}{l}\text { Lambda ZAP Express }{ }^{c} / E \text {. } \\
\text { coli XL1 blue }\end{array}$ & 10000 & CMC & $1 / 10.000$ & $\begin{array}{l}\text { Wang et al. } \\
(2009)[52]\end{array}$ \\
\hline Elephant dung & & 10000 & CMC & $1 / 5.000$ & $\begin{array}{l}\text { Wang et al. } \\
(2009)[52]\end{array}$ \\
\hline \multirow[t]{3}{*}{ Cow rumen } & \multirow[t]{3}{*}{ pCCFOS $^{\text {b }}$ / E. coli EPI300 } & 12288 & pNP-alpha-galactopyranoside & $1 / 12.288$ & \multirow{3}{*}{$\begin{array}{l}\text { Ferrer et al. } \\
\text { (2012) [27] }\end{array}$} \\
\hline & & 12288 & pNP-alpha-L-arabinofuranoside & $1 / 4.096$ & \\
\hline & & 12288 & CMC & $1 / 6.144$ & \\
\hline Alkaline-polluted soil & pGEM-3Zf ${ }^{c} /$ E. coli DH5a & 30000 & Esculine & $1 / 15.000$ & $\begin{array}{l}\text { Jiang et al. } \\
\text { (2011) [53] }\end{array}$ \\
\hline Soil & $\begin{array}{l}\text { pHBM803 c / E. coli XL10- } \\
\text { Gold }\end{array}$ & 24000 & Remazol brilliant blue dyed-xylan & $1 / 24.000$ & $\begin{array}{l}\text { Hu et al. } \\
(2008)[54]\end{array}$ \\
\hline${ }^{13} \mathrm{C}$-cellulose-enriched DNA (soil) ${ }^{\mathrm{e}}$ & pJC8 d / E. coli HB101 & 2876 & CMC & $1 / 360$ & $\begin{array}{l}\text { Verastegui et al. } \\
\text { (2014) [40] }\end{array}$ \\
\hline $\begin{array}{l}\text { Wheat straw- enrichment culture } \\
\text { (soil) }\end{array}$ & \multirow[t]{2}{*}{ pCC2FOS ${ }^{\text {b }}$ / E. coli EPI300 } & 22000 & Mixture of 6 indolyl-monosaccharides & $1 / 440$ & \multirow[t]{2}{*}{ This study } \\
\hline $\begin{array}{l}\text { Torrefied wheat straw- enrichment } \\
\text { culture (soil) }\end{array}$ & & 22000 & Mixture of 6 indolyl-monosaccharides & $1 / 1,047$ & \\
\hline
\end{tabular}

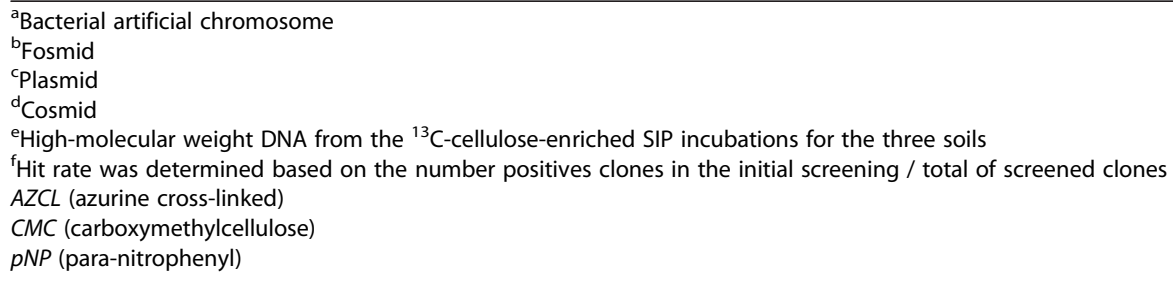


predicted alpha-glucosidase activity. However, the detected genes for family GH58 (endo-N-acetylneuraminidase) and family GH27 (alpha-galactosidase) proteins might encode the activity (see Additional file 8 for a summary of activities associated with CAZy enzyme families described in this study). Similarly, fosmid NT18-21 showed alpha-glucosidase activity, with no GH family genes being detected in the insert. In this fosmid, genes for maltose/maltodextrin transporters were found. Maltose (an alpha 1-4 linked glucose dimer) resembles a cellulose dimer (albeit beta 1-4 linked). Maltose is released from starch by amylose/amylopectin-degrading activity (e.g. GH13- alpha-amylase, pullulanase or alpha-glucosidase). We surmised that starch that was initially present in the wheat straw used for consortium breeding incited the selection of such systems. The chromogenic substrates, e.g. X-Glu, used in this study were surmised to report alpha-glucosidase activities, but genes for such enzymes were not detected. Possibly, gene 25 (annotated as an alpha-aspartyl dipeptidase; EC 3.4.13.21) or gene 24 (hypothetical protein) were responsible for the activity (Additional file 6).

Fosmid clone 10BT showed consistent activity only on mixed substrates. In addition, 10BT showed activity on pNPXyl, much below that shown by clone T5-5 $\left(\sim 14,8 \%\right.$ of relative activity at $40{ }^{\circ} \mathrm{C}, \mathrm{pH} 7.0$; Fig. $\left.3 \mathrm{~d}\right)$. The finding of two genes producing proteins related to GH39 and GH53 families was revealing. Interestingly, family GH39 proteins have been linked to betaxylosidase and alpha-L-iduronidase activities. Moreover, GH53 family proteins can have beta-1,4-galactanase activity (EC 3.2.1.89). The latter is possibly linked to the degradation of galactans and arabinogalactans, both integral parts of the pectin component of plant cell walls [42]. Interestingly, Jiménez et al. [43] recently found a novel cold-tolerant esterase, which had originally been annotated as a MarR family transcriptional regulator. Thus, we surmised that the gene that was originally predicted to encode an $\mathrm{AraC}$ transcriptional regulator may be responsible for the activity on pNPXyl. Similar to clone T4-1, this clone could require the presence of other types of substrates to enable detection of its full plethora of activities. However, given that we still don't know the mechanism involved, further studies are required, for example subcloning, transposon mutagenesis and detection of activities on different substrates.

The high activity of fosmid NT2-2 compared to that of clones T5-5 and NT18-17 suggested a raised expression of the gene encoding beta-galactosidase $(\sim 116 \mathrm{kDa}$, as evident by the zymogram; Fig. 5). Interestingly, the high activities of clones NT2-2 and T5-5 at $55{ }^{\circ} \mathrm{C}$ and $\mathrm{pH} 10.0$ pointed to their potential usefulness in pulp bleaching processes. The novelty attributed to these genes ( 3 and 12) was based on the low amino acid identities (less than $84 \%$ ) and coverage values (less than $91 \%$ ) versus the best hits in the NCBI database (Table 3). The functional analysis done by us directly from the metagenomic clones indicated substrate specificities and temperature/pH optima, and constitutes an easy way to select clones useful for biotechnology applications. In addition, subcloning, overexpression, induction and subsequent protein purification are labor-intensive and not always successful (e.g. due to low solubility of the enzyme).

The leading industrial source of cellulase cocktails used for plant biomass biodegradation purposes is Trichoderma reesei. Several strains exist and their secretomes have been widely used to develop new commercial cocktails. However, T. reesei secretomes are dominated by endoglucanases and it usually produces low quantities of xylanases, arabinofuranosidases, galactosidases and beta-glucosidases. Hence, addition of exogenous enzymes to the secreted fraction could improve the hydrolytic efficiency [44]. Based on this premise, the enzymes detected in clones NT2-2, T5-5 and NT18-17 might serve as components of new (hemi)cellulolytic cocktails. These may be combined with the commercial cellulases to improve plant biomass degradation for second-generation biofuel production. Additionally, thermo-alkaliphilic xylosidases are valuable with respect to their usefulness in pulp bleaching processes $[13,14]$.

In a previous study [45], Bacteroidetes-related genes for hemicellulases were found to be prominent amongst the dominant enzymes, whereas Klebsiella-related ones were less abundant. Both groups of organisms are key dominant types in our bacterial consortia bred on wheat straw. In the current study, evidence was found for the contention that Klebsiella-related organisms were at the basis of most cloned genes for biodegradative enzymes. The taxonomic closeness between this putative source organism (Klebsiella) and the heterologous host (E. coli) used, versus the remoteness in the case of Bacteroidetes, may have been a key factor explaining this finding. Unfortunately, the current study did not detect fosmids with activities on X-Fuc and X-Man. Such activities might be mostly associated with members of the Bacteroidetes (e.g. Sphingobacterium), as recently indicated by Jiménez et al. [45]. Finally, the differential association of fosmid NT2-2 and 10BT genes with Pseudomonas putida versus Klebsiella sp. was remarkable. IS-elements indicative of horizontal gene transfer were not detected, suggesting these fosmids might originate from fusions of two regions originating from different parental organisms. Alternatively, the insert may have come from a new Gammaproteobacteria species. 


\section{Conclusions}

Here, we propose a multi-substrate screening approach as a sound strategy that allows to detect multiple activities in a single initial assay. This methodology is less time-consuming than single-substrate approaches and can even be applied in high-throughput set-ups, as in agar plates. The strategy yielded high hit rates of genes for relevant enzymes compared with recent relevant literature data. Based on this methodology, we retrieved fosmids with beta-galactosidase, beta-xylosidase and alpha-glucosidase activities, whereas other fosmids showed activity only in the presence of mixed chromogenic substrates. Two fosmids, NT2-2 (GH2- beta-galactosidase) and T5-5 (GH3- beta-xylosidase), showed enzymatic activities at high temperatures and $\mathrm{pH}$ values, making these clones interesting sources for future biotechnological applications.

\section{Methods}

\section{Metagenomic DNA extraction from lignocellulolytic} microbial consortia

The lignocellulolytic microbial consortia examined here were primed with a forest soil derived microbial source. Briefly, the microbial cells were introduced into triplicate flasks containing $25 \mathrm{ml}$ of mineral salt medium (MSM) with $1 \%$ of $i$ ) "raw" wheat straw (RWS) and ii) heattreated $\left(240{ }^{\circ} \mathrm{C}, 1 \mathrm{~h}\right)$ wheat straw (TWS), after which flasks were incubated at $25{ }^{\circ} \mathrm{C}$ with shaking at $100 \mathrm{rpm}$. A sequential-batch approach was followed up to the $10^{\text {th }}$ transfer [19-35]. Then, DNA was extracted from the $10^{\text {th }}$ transfer microbial consortia, by using the UltraClean $^{\bullet}$ Microbial DNA Isolation Kit (MoBio Laboratories Inc., USA). Three replicate crude DNA extracts were pooled for each fosmid library and concentrated up to $250 \mathrm{ng} / \mu \mathrm{l}$ using a Speedvac concentrator (Eppendorf, Hamburg, Germany).

\section{Construction of metagenomic libraries in fosmids}

Metagenomic libraries were constructed using the CopyControl $^{\text {TM }}$ HTP Fosmid Library Production Kit (Epicentre Biotechnologies, Madison, USA). Briefly, the metagenomic DNA was partially sheared by pipetting, to yield DNA fragments between 30 to $50 \mathrm{~kb}$, after which it was 5 'phosphorylated / blunt-ended. The DNA was then analyzed in $1 \%$ low-melting-point agarose using a CHIEF-DR III pulsed field gel electrophoresis system (BioRad, Hercules, USA) at $14{ }^{\circ} \mathrm{C}$ with the following parameters: gradient $6 \mathrm{~V} / \mathrm{cm}$, included angle $120^{\circ}$, initial switch time $0.5 \mathrm{~s}$, final switch time $8.5 \mathrm{~s}$, linear ramping factor, $18 \mathrm{~h}$. DNA fragments of approximately $30-40 \mathrm{~Kb}$ were excised from the gel and recovered using Zymoclean ${ }^{\mathrm{TM}}$ Large Fragment DNA Recovery Kit (Zymo Research, Irvine, USA). The DNA was then ligated into vector pCC2FOS, packaged in phage particles and competent E. coli EPI300-T1 ${ }^{\mathrm{R}}$ cells were transformed with it. The E. coli cells were diluted $1: 10^{3}$ and plated onto $1 \%$ LB agar supplemented with $12.5 \mu \mathrm{g} / \mathrm{ml}$ chloramphenicol $(\mathrm{LBA}+\mathrm{Cm})$. Plates were incubated overnight at $37^{\circ} \mathrm{C}$, to produce 500 to 600 colonies per plate. The colonies of each plate were pooled in $1 \mathrm{ml}$ of LB broth with $20 \%$ of glycerol and stored as fosmid pools at $-80{ }^{\circ} \mathrm{C}$ for further analysis.

\section{Screening for fosmid clones expressing (hemi)cellulolityc enzymes}

Screening was done in three steps. First, fosmid pools stored at $-80{ }^{\circ} \mathrm{C}$ were recovered in $100 \mu \mathrm{LB}$ broth at $37{ }^{\circ} \mathrm{C}$ for $1 \mathrm{~h}$ (shaking at $250 \mathrm{rpm}$ ) and serially diluted up to $1: 10^{5}$. Then, each suspension $(100 \mu \mathrm{l})$ was plated on $\mathrm{LBA}+\mathrm{Cm}$ supplemented with a mix of each of the six chromogenic substrates (at $40 \mu \mathrm{g} / \mathrm{ml}$ ) (Table 1). After incubation $\left(48 \mathrm{~h}, 37^{\circ} \mathrm{C}\right)$, dark blue colonies (due to hydrolysis of the chromogenic substrate) were selected, purified to obtain single colonies and retested. Secondly, selected clones were plated onto LBA $+\mathrm{Cm}$ supplemented with each of the specific hemicellulosemimicking substrates, i.e. X-Fuc, X-Gal, X-Man and $\mathrm{X}-\mathrm{Xyl}$, in single, double, triple and quadruple combinations. Thirdly, clones that were positive in the first screening (on six substrates) and negative in the second screening (four substrates in different combinations) were further tested on X-Cel and X-Glu (single and double combinations) (Fig. 1).

\section{Extraction of DNA from selected fosmid clones}

Selected positive clones were cultured in $4 \mathrm{ml}$ of LB supplemented with $12.5 \mu \mathrm{l} / \mathrm{ml}$ chloramphenicol $(\mathrm{LB}+\mathrm{Cm})$ and incubated at $250 \mathrm{rpm}$ for $8 \mathrm{~h}$ at $37{ }^{\circ} \mathrm{C}$. After incubation, $25 \mu \mathrm{l}$ was used to inoculate $25 \mathrm{ml}$ of fresh $\mathrm{LB}+$ $\mathrm{Cm}$. To increase the fosmid copy numbers, $50 \mu \mathrm{l}$ of autoinduction solution (500X) (Epicentre Biotechnologies, Madison, USA) were added and flasks incubated $\left(37{ }^{\circ} \mathrm{C}\right.$, shaking at $250 \mathrm{rpm}$ ). At $\mathrm{OD}_{600}$ of about 2-2.5, fosmid DNA was extracted from these cultures using the Gene Jet Plasmid Midi Preparation Kit (Thermo Scientific, Waltham, USA). DNA size and integrity were verified by running aliquots of the DNA on $1 \%$ agarose gels and DNA concentration was measured by spectrophotometry (Nanodrop 2000; Thermo Scientific). The resulting fosmid DNA was digested with EcoR1 and the restriction patterns were analyzed on $0.8 \%$ agarose gels. Band sizes were estimated by comparison to a standard DNA marker (GeneRuler ${ }^{\mathrm{TM}} 1 \mathrm{~Kb}$ ladder, Thermo Scientific). The size of the insert of each fosmid was estimated by calculating the sum of the sizes of the individual EcoR1 generated bands minus 8,181 bp (fosmid backbone). 


\section{Sequencing and gene annotation of fosmid inserts}

The selected positive fosmid clones were sequenced using the Illumina HiSeq platform (2 X 100 bp). Sequences from the E. coli EPI300 genome as well as vector backbone sequences were removed. The resulting set of raw sequence data was quality-checked and further processed, with normalization and Velvet-based de novo assembly to generate contigs (Beckman Coulter Genomics, Danvers, USA). Contigs were selected from the data if the average coverage exceeded 200-fold, and final contigs were considered to be representative of the whole insert. ORFs were assigned to each of the contigs using the Rapid Annotation Subsystems Technology (RAST) server [46]. Subsequently, the ORFs were annotated in the CAZymes Analysis Toolkit (CAT) platform [47], using default parameters. Finally, all genes predicted in each fosmid insert were re-annotated and verified (inhouse) using BLASTX searches against the NCBI database. The results from this analysis were loaded into MEGAN v5 software [48], after which they were classified taxonomically using the suggested parameters for the LCA algorithm (maximum number of matches per read 10; minimal support 5; minimal score 35; max expected 0.01 ; minimal complexity 0.3 ; and top percent 10 ). The nucleotide sequences of the contigs retrieved from the clones NT2-2, T5-5, NT18-17, T4-1, 10BT, NT18-21 and T17-2 were deposited in the GenBank database under the accession numbers KU505133-KU505147.

\section{Functional analyses - beta-galactosidase, beta-xylanase and alpha-glucosidase activity assays}

Positive clones were grown $\left(37^{\circ} \mathrm{C}\right.$, shaking at $\left.250 \mathrm{rpm}\right)$ in $5 \mathrm{ml} \mathrm{LB}+\mathrm{Cm}$ containing $10 \mu \mathrm{l}$ of auto-induction solution (500X). At $\mathrm{OD}_{600}$ of 0.5 , cells were harvested by centrifugation (10 $\mathrm{min}, 10,000 \mathrm{~g})$. Proteins were extracted by adding $2 \mathrm{ml}$ of lysis buffer $(20 \mathrm{mM}$ Tris $-\mathrm{HCl}$ $\mathrm{pH}$ 7.5, $100 \mathrm{mM} \mathrm{NaCl}, 1 \mathrm{mM}$ EDTA, $0.1 \%$ Triton, $5 \mathrm{mM}$ CHAPS and a tablet of protease inhibitor -Rocheto $50 \mathrm{ml}$ ) to the pellet. Subsequently, the mixtures were sonicated on ice (6 s on, $15 \mathrm{~s}$ off, 30 cycles with amplitude of 10-15 microns). Protein concentration was determined by the Bradford method using bovine serum albumin as standard. The total protein fractions were recovered and tested for activity using pNPGal, pNPXyl and pNPGlu. The reaction mixture consisted of $0.3 \mathrm{ml}$ of $10 \mathrm{mM}$ pNPGal, pNPXyl or pNPGlu (diluted in $50 \mathrm{mM}$ of Tris- $\mathrm{HCl} \mathrm{pH} \mathrm{7.0)}$ and $0.3 \mathrm{~mL}$ of each clone protein fraction. The mixtures were incubated at $40{ }^{\circ} \mathrm{C}$ for $30 \mathrm{~min}$ to $2 \mathrm{~h}$ (depending on the quantity of proteins and activity) and the reactions were stopped on ice. Two negative controls were used for all assays: $i$ ) reaction mixture without substrate and $i$ ) reaction mixture using the total protein fraction from the fosmid-less host $E$. coli EPI300. Enzymatic activities were determined from the measured absorbance units using a standard calibration curve. The amount of para-nitrophenol liberated was measured by absorbance at $410 \mathrm{~nm}$. One unit (U) of enzyme activity was defined as the activity required for the formation of $1 \mu \mathrm{M}$ of pNP per min under the above conditions (in this case $\mathrm{mg}$ of total protein). Optimum temperature was determined in the range of $4-80{ }^{\circ} \mathrm{C}$ using pNPGal, pNPXyl and pNPGlu (at $\mathrm{pH} 7.0$ and 9.0). The $\mathrm{pH}$ optimum was determined in a $\mathrm{pH}$ range from 3.0 to 10.0 (at $40{ }^{\circ} \mathrm{C}$ and $55^{\circ} \mathrm{C}$ ) under standard conditions using the following buffers: $50 \mathrm{mM}$ sodium citrate ( $\mathrm{pH} 3.0$ to 6.0 ), $50 \mathrm{mM}$ Tris- $\mathrm{HCl}$ (pH 7.0-9.0) and $50 \mathrm{mM}$ glycine- $\mathrm{NaOH}$ (pH 10.0).

\section{Protein electrophoresis and zymographic analyses}

Zymograms were used to detect beta-galactosidase and beta-xylosidase activities on native polyacrylamide gels (4\% stacking, $10 \%$ resolving gels) using $40 \mu \mathrm{g}$ of total protein per sample. After running the gels at $4{ }^{\circ} \mathrm{C}$, they were washed with water and then incubated with $5 \mathrm{mM}$ of each substrate (MUFGal and MUFXyl) diluted in $0.1 \mathrm{M}$ of Tris- $\mathrm{HCl}(\mathrm{pH} 8.0)$ at $25{ }^{\circ} \mathrm{C}$ for $1 \mathrm{~h}$. Following this, bands were visualized under UV light.

\section{Availability of supporting data}

All the supporting data are included as additional files

\section{Additional files}

Additional file 1: Complete gene annotation of fosmid insert NT2-2. (XLS $41 \mathrm{~kb}$ )

Additional file 2: Complete gene annotation of fosmid insert T5-5. (XLS 42 kb)

Additional file 3: Complete gene annotation of fosmid insert NT18-17. (XLS $43 \mathrm{~kb}$ )

Additional file 4: Complete gene annotation of fosmid insert T4-1. (XLS $43 \mathrm{~kb}$ )

Additional file 5: Complete gene annotation of fosmid insert 10BT. (XLS $43 \mathrm{~kb}$ )

Additional file 6: Complete gene annotation of fosmid insert NT18-21. (XLS $39 \mathrm{~kb}$ )

Additional file 7: Complete gene annotation of fosmid insert T17-2. (XLS 36 kb)

Additional file 8: Summary of activities associated with CAZy enzyme families described in this study. (XLS $40 \mathrm{~kb}$ )

\section{Abbreviations}

AAs: auxiliary activities; AZCL: Azurine cross-linked polysaccharides;

CAZy: carbohydrate-active enzyme database; CBMs: carbohydrate-binding modules; CEs: carbohydrate esterases; CMC: Carboxymethyl cellulose;

GHs: glycosyl hydrolases; GTs: glycosyl transferases; LCA: lowest common ancestor algorithm; MUF: 4-methylumbelliferyl; ORF: open reading frame; pNP: para-nitrophenyl; pNPGal: para-nitrophenyl beta-D-galactopyranoside; pNPGlu: para-nitrophenyl alpha-D-glucopyranoside; pNPXyl: para-nitrophenyl beta-D -xylanopyranoside; RAST: rapid Annotations using Subsystems Technology; X-Cel: 5-bromo-4-chloro-3-indolyl- $\beta$-D-cellobioside; X-Fuc: 5bromo-4-chloro-3-indolyl- -L-fucopyranoside; X-Gal: 5-bromo-4-chloroindolyl- $\beta$-D-galactopyranoside; X-Glu: 5-bromo-4-chloro-3-indolyl- -D- 
glucopyranoside; X-Man: 5-bromo-4-chloro-3-indolyl -D-mannopyranoside X-Xyl: 5-bromo-4-chloro-3-indolyl- $\beta-D-x y l o p y r a n o s i d e$.

\section{Competing interests}

The authors declare that they have no competing interests.

\section{Authors' contributions}

MM performed most of the experiments, particularly the zymograms. DJJ helped to design the experiments, participated in the sequence analyses, performed the enzymatic assays and drafted the manuscript. PS contributed to the functional screening procedures. JDvE conceived the study, participated in its design and coordination and contributed to the drafting of the manuscript. All authors read and approved the final manuscript.

\section{Acknowledgements}

We thank F. Dini-Andreote for his critical review of the manuscript and D. Devlitsarov for experimental support. Further thanks are due to $H$. Ruijssenaars and R. van Kranenburg for their scientific support. This work was supported by the Netherlands Ministry of Economic Affairs and the BE-Basic partner organizations (http://www.be-basic.org/).

\section{Received: 3 September 2015 Accepted: 18 January 2016}

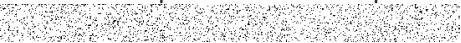

\section{References}

1. Limayem A, Ricke SC. Lignocellulosic biomass for bioethanol production: Current perspectives, potential issues and future prospects. Prog Energy Combust Sci. 2012;38:449-67.

2. Himmel ME, Xu Q, Luo Y, Ding SY, Lamed R, Bayer EA. Microbial enzyme systems for biomass conversion: Emerging paradigms. Biofuels. 2010;1:323-41.

3. Dougherty MJ, D'haeseleer P, Hazen TC, Simmons BA, Adams PD, Hadi MZ Glycoside hydrolases from a targeted compost metagenome, activityscreening and functional characterization. BMC Biotechnol. 2012;12:38.

4. De Souza RW. Microbial degradation of lignocellulosic biomass. In: Chandel A, Da Silva, S. Sustainable degradation of lignocellulosic biomass - techniques, applications and commercialization. Brazil: InTech; 2013. doi: $10.5772 / 54325$

5. Turner P, Mamo G, Karlsson E. Potential and utilization of thermophiles and thermostable enzymes in biorefining. Microb Cell Fact. 2007;6:9.

6. Sims REH, Mabee W, Saddler JN, Taylor M. An overview of second generation biofuel technologies. Bioresour Technol. 2010;101:1570-80.

7. Himmel ME, Ding SY, Johnson DK, Adney WS, Nimlos MR, Brady JW, et al. Biomass recalcitrance: engineering plants and enzymes for biofuels production. Science. 2007:315:804-7.

8. Gowen CM, Fong SS. Exploring biodiversity for cellulosic biofuel production. Chem Biodivers. 2010;7:1086-97.

9. Xing MN, Zhang $X Z$, Huang $H$. Application of metagenomic techniques in mining enzymes from microbial communities for biofuel synthesis. Biotechnol Adv. 2012;30(4):920-9.

10. Jayani RS, Saxena S, Gupta R. Microbial pectinolytic enzymes: A review Process Biochem. 2005:40:2931-44.

11. Gilbert HJ, Stålbrand H, Brumer H. How the walls come crumbling down: Recent structural biochemistry of plant polysaccharide degradation. Curr Opin Plant Biol. 2008;11:338-48.

12. Sweeney MD, Xu F. Biomass converting enzymes as industrial biocatalysts for fuels and chemicals: Recent developments. Catalysts. 2012;2:244-63.

13. Clarke JH, Davidson K, Rixon JE, Halstead JR, Fransen MP, Gilbert HJ, et al. A comparison of enzyme-aided bleaching of softwood paper pulp using combinations of xylanase, mannanase and alpha-galactosidase. Appl Microbiol Biotechnol. 2000;53(6):661-7.

14. Sudha B, Veeramani $H$, Sumathi S. Bleaching of bagasse pulp with enzyme pre-treatment. Water Sci Technol. 2003;47(10):163-8.

15. Gao D, Uppugundla N, Chundawat SP, Yu X, Hermanson S, Gowda K, et al. Hemicellulases and auxiliary enzymes for improved conversion of lignocellulosic biomass to monosaccharides. Biotechnol Biofuels. 2011;4:5.

16. Del Pozo MV, Fernández-Arrojo L, Gil-Martínez J, Montesinos A, Chernikova TN, Nechitaylo TY, et al. Microbial $\beta$-glucosidases from cow rumen metagenome enhance the saccharification of lignocellulose in combination with commercial cellulase cocktail. Biotechnol Biofuels. 2012;5:73.
17. Wongwilaiwalin S, Rattanachomsri U, Laothanachareon T, Eurwilaichitr L, garashi Y, Champreda V. Analysis of a thermophilic lignocellulose degrading microbial consortium and multi-species lignocellulolytic enzyme system. Enzyme Microb Technol. 2010;47:283-90.

18. Wang W, Yan L, Cui Z, Gao Y, Wang Y, Jing R. Characterization of a microbial consortium capable of degrading lignocellulose. Bioresour Technol. 2011;102:9321-4.

19. Jiménez DJ, Korenblum E, van Elsas JD. Novel multispecies microbial consortia involved in lignocellulose and 5-hydroxymethylfurfural bioconversion. Appl Microbiol Biotechnol. 2014;98:2789-803.

20. Cheng J, Zhu M. A Novel co-culture strategy for lignocellulosic bioenergy production: A systematic review. Int J Mod Biol Med. 2012;1:166-93.

21. Deangelis KM, D'Haeseleer $P$, Chivian D, Simmons B, Arkin AP, Mavromatis K, et al. Metagenomes of tropical soil-derived anaerobic switchgrass-adapted consortia with and without iron. Stand Genomic Sci. 2013;7:382-98.

22. Wongwilaiwalin S, Laothanachareon T, Mhuantong W, Tangphatsornruang $S$, Eurwilaichitr L, Igarashi $Y$, et al. Comparative metagenomic analysis of microcosm structures and lignocellulolytic enzyme systems of symbiotic biomass-degrading consortia. Appl Microbiol Biotechnol. 2013;97:8941-54.

23. Zhou Y, Pope PB, Li S, Wen B, Tan F, Cheng S, et al. Omics-based interpretation of synergism in a soil-derived cellulose-degrading microbial community. Sci Rep. 2014:4:5288.

24. Simon C, Daniel R. Achievements and new knowledge unraveled by metagenomic approaches. Appl Microbiol Biotechnol. 2009;85:265-76.

25. Li LL, Taghavi S, McCorkle SM, Zhang YB, Blewitt MG, Brunecky R, et al. Bioprospecting metagenomics of decaying wood: mining for new glycoside hydrolases. Biotechnol Biofuels. 2011;4(1):23.

26. Allgaier M, Reddy A, Park Jl, Ivanova N, D'haeseleer P, Lowry S, et al. Targeted discovery of glycoside hydrolases from a switchgrass-adapted compost community. PLoS ONE. 2010;5:e8812

27. Ferrer M, Ghazi A, Beloqui A, Vieites JM, López-Cortés N, Marín-Navarro J, et al. Functional metagenomics unveils a multifunctional glycosyl hydrolase from the family 43 catalysing the breakdown of plant polymers in the calf rumen. PLOS ONE. 2012;7:e38134.

28. Nacke H, Engelhaupt M, Brady S, Fischer C, Tautzt J, Daniel R. Identification and characterization of novel cellulolytic and hemicellulolytic genes and enzymes derived from German grassland soil metagenomes. Biotechnol Lett. 2012;34:663-75.

29. Mori T, Kamei I, Hirai H, Kondo R. Identification of novel glycosyl hydrolases with cellulolytic activity against crystalline cellulose from metagenomic libraries constructed from bacterial enrichment cultures. Springerplus. 2014;3:365.

30. Beloqui A, Nechitaylo TY, López-Cortés N, Ghazi A, Guazzaroni ME, Polaina J, et al. Diversity of glycosyl hydrolases from cellulose-depleting communities enriched from casts of two earthworm species. Appl Environ Microbiol. 2010;76:5934-46.

31. Ekkers DM, Cretoiu MS, Kielak AM, van Elsas JD. The great screen anomaly-a new frontier in product discovery through functional metagenomics. Appl Microbiol Biotechnol. 2012;93:1005-20.

32. Bastien G, Arnal G, Bozonnet S, Laguerre S, Ferreira F, Fauré R, et al. Mining for hemicellulases in the fungus-growing termite Pseudacanthotermes militaris using functional metagenomics. Biotechnol Biofuels. 2013;6:78.

33. Lämmle K, Zipper $\mathrm{H}$, Breuer M, Hauer B, Buta $\mathrm{C}$, Brunner $\mathrm{H}$, et al. Identification of novel enzymes with different hydrolytic activities by metagenome expression cloning. J Biotechnol. 2007;127:575-92.

34. Ferrer M, Martínez-Martínez M, Bargiela R, Streit WR, Golyshina OV, Golyshin $\mathrm{PN}$. Estimating the success of enzyme bioprospecting through metagenomics: current status and future trends. Microb Biotechnol. 2015. doi: 10.1111/1751-7915.12309. [Epub ahead of print]

35. Jiménez DJ, Dini-Andreote F, van Elsas JD. Metataxonomic profiling and prediction of functional behaviour of wheat straw degrading microbial consortia. Biotechnol Biofuels. 2014:7:92

36. Uchiyama T, Miyazaki K. Functional metagenomics for enzyme discovery: Challenges to efficient screening. Curr Opin Biotechnol. 2009;20:616-22.

37. Gould SW, Chadwick M, Cuschieri P, Easmon S, Richardson AC, Price RG, et al. The evaluation of novel chromogenic substrates for the detection of lipolytic activity in clinical isolates of Staphylococcus aureus and MRSA from two European study groups. FEMS Microbiol Lett. 2009:297:10-6.

38. Zhao S, Wang J, Bu D, Liu K, Zhu Y, Dong Z, et al. Novel glycoside hydrolases identified by screening a Chinese Holstein dairy cow rumenderived metagenome library. Appl Environ Microbiol. 2010;76:6701-5. 
39. Nguyen NH, Maruset L, Uengwetwanit T, Mhuantong W, Harnpicharnchai P, Champreda $\mathrm{V}$, et al. Identification and characterization of a cellulaseencoding gene from the buffalo rumen metagenomic library. Biosci Biotechnol Biochem. 2012;76(6):1075-84.

40. Verastegui Y, Cheng J, Engel K, Kolczynski D, Mortimer S, Lavigne J, et al. Multisubstrate isotope labeling and metagenomic analysis of active soil bacterial communities. MBio. 2014;5:e01157-14.

41. Kračun SK, Schückel J, Westereng B, Thygesen LG, Monrad RN, Eijsink VGH, et al. A new generation of versatile chromogenic substrates for high-throughput analysis of biomass-degrading enzymes. Biotechnol Biofuels. 2015:8:70.

42. Hinz SW, Pastink MI, van den Broek LA, Vincken JP, Voragen AG. Bifidobacterium longum endogalactanase liberates galactotriose from type I galactans. Appl Environ Microbiol. 2005;71:5501-10.

43. Jiménez DJ, Montaña JS, Alvarez D, Baena S. A novel cold active esterase derived from Colombian high Andean forest soil metagenome. World J Microbiol Biotechnol. 2012;28:361-70.

44. Mohanram S, Amat D, Choudhary J, Arora A, Nain L. Novel perspectives for evolving enzyme cocktails for lignocellulose hydrolysis in biorefineries. Sustain Chem Process. 2013;1:15.

45. Jiménez DJ, Chaves-Moreno D, van Elsas JD. Unveiling the metabolic potential of two soil-derived microbial consortia selected on wheat straw. Sci Rep. 2015;5:13845.

46. Aziz RK, Bartels D, Best AA, DeJongh M, Disz T, Edwards RA, et al. The RAST Server: rapid annotations using subsystems technology. BMC Genomics. 2008;9:75.

47. Park BH, Karpinets TV, Syed MH, Leuze MR, Uberbacher EC. CAZymes Analysis Toolkit (CAT): Web service for searching and analyzing carbohydrate-active enzymes in a newly sequenced organism using CAZy database. Glycobiology. 2010;20:1574-84.

48. Huson DH, Weber N. Microbial community analysis using MEGAN. Methods Enzymol. 2013;531:465-485

49. Vester JK, Glaring MA, Stougaard P. Discovery of novel enzymes with industrial potential from a cold and alkaline environment by a combination of functional metagenomics and culturing. Microb Cell Fact. 2014;13:72.

50. Tasse L, Bercovici J, Pizzut-Serin S, Robe P, Tap J, Klopp C, et al. Functional metagenomics to mine the human gut microbiome for dietary fiber catabolic enzymes. Genome Res. 2010;20:1605-12.

51. Jeong YS, Na HB, Kim SK, Kim YH, Kwon EJ, Kim J, et al. Characterization of xyn10J, a novel family 10 xylanase from a compost metagenomic library. Appl Biochem Biotechnol. 2012;166:1328-39.

52. Wang F, Li F, Chen G, Liu W. Isolation and characterization of novel cellulase genes from uncultured microorganisms in different environmental niches. Microbiol Res. 2009:164:650-7.

53. Jiang C, Li SX, Luo FF, Jin K, Wang Q, Hao ZY, et al. Biochemical characterization of two novel $\beta$-glucosidase genes by metagenome expression cloning. Bioresour Technol. 2011;102:3272-8.

54. Hu Y, Zhang G, Li A, Chen J, Ma L. Cloning and enzymatic characterization of a xylanase gene from a soil-derived metagenomic library with an efficient approach. Appl Microbiol Biotechnol. 2008;80:823-30.

\section{Submit your next manuscript to BioMed Central and we will help you at every step:}

- We accept pre-submission inquiries

- Our selector tool helps you to find the most relevant journal

- We provide round the clock customer support

- Convenient online submission

- Thorough peer review

- Inclusion in PubMed and all major indexing services

- Maximum visibility for your research

Submit your manuscript at www.biomedcentral.com/submit

C Biomed Central 